\title{
17. CARBONATE SEDIMENTARY ROCKS FROM THE WESTERN PACIFIC: LEG 7, DEEP SEA DRILLING PROJECT
}

\author{
Ralph Moberly, Jr., Hawaii Institute of Geophysics, University of Hawaii, Honolulu, Hawaii \\ and \\ G. Ross Heath, Department of Oceanography, Oregon State University, Corvallis, Oregon
}

\begin{abstract}
Cenozoic calcareous oozes, chalks and limestones drilled during Leg 7 are mainly biomicrites. Foraminifera, and lesser amounts of radiolarians, are in an abundant matrix of nannofossils and broken foraminifers. The faint parallel lamination and diagenetic changes leading to induration are described and illustrated with photomicrographs.
\end{abstract}

Sediments containing more than 70 per cent calcium carbonate dominate the sequences cored at Sites 62 , 63 and 64. A few sections of cores from Site 65 contained about 15 to 40 per cent carbonate. At other Leg 7 sites, sediments generally contain less than 1 per cent carbonate.

The carbonates are chalk oozes, chalks and limestones of pelagic origin. With the exception of a few rare foraminiferal turbidite beds in radiolarian ooze sections, the carbonates are dominantly microcrystalline calcite (Figures 1 and 2). The micrite is composed of whole and fragmented coccoliths, discoasters, small fragments of foraminiferal tests, and particles too fine to identify but probably the finest particles of broken nannofossils and foraminifers. Less abundant are whole tests and larger fragments of foraminifers which constitute from 0 to about 40 per cent of the samples in the smear slides and thin sections. Clay, glass shards and other volcanic debris, radiolarian tests, pyrite, and other components are present in varying amounts. These sediments can be classified as biomicrite, calcilutite, or nannofossil (nannoplankton) oozes and chalks.

Primary sedimentary structures are common but usually indistinct. Where it can be discerned, bedding is parallel. It can be seen only at lithological boundaries, such as between ash-rich and ash-poor beds, and where textural variation within the carbonate reveal fine lamination. For instance, foraminifer-rich layers 0.5 to 3 millimeters apart can be seen in some thin sections (Figures 3 and 4) or on smoothed surfaces. The fabric of such sediments shows a preferred orientation of the long axes of whole and broken foraminifers that is parallel to the lamination (Figure 5). These sediments are sparsely packed, that is to say, the sand-sized foraminiferal and radiolarian tests are mainly separated by the micrite matrix and only rarely touch one another (Figures 1, 2 and 5).
Mottles are most evident in the younger parts of the carbonate sections, where they show by color contrast rather than by local textural changes. In the upper parts of the holes the oozes are greenish grays, pale purple and light grays, whereas at depth the chalks are whitish greens, white and very pale grays. The rocks of little chroma show few mottles, except for purplish ones, due to pyrite. However, the same rocks have portions where textural and fabric layering is evident adjacent to portions where it is not. The latter portions were probably burrowed, but do not show mottles because of the light color of the rocks.

Some of the changes in the sediment with increasing depth in the holes apparently are due to changes in sedimentation with time, and some to diagenesis. The decrease in clay content at Site 63, from marls at the sea floor to chalk oozes below, almost certainly resulted from a change in sedimentation. Probably it was due to subsidence of the crust or to a rise in the calcite compensation depth in the latest Cenozoic, and thereby a decrease in carbonate sedimentation. On the other hand, increases in induration and decreases in chroma are diagenetic. Almost certainly the decrease in radiolarian abundance with depth in the carbonate sections is diagenetic. Probably the increased geoisotherms of the more deeply-buried sediments affected the solubility of the amorphous silica, thus also accounting for the corroded aspect of the remaining grains.

As was pointed out in the summaries for the various sites, the most significant change in the carbonates at each site is their increasing induration (Figures 6, 7 and 8). Much of the induration results from increased grain-to-grain adhesion as the pore water is forced out during compaction of the sediments. Some of the limestones and deeper chalks have calcite overgrowths on foraminifers and nannofossils, and contain clots of nannofossils that are difficult to disperse, indicating some cementation. 
TABLE 1

Inter-laboratory Comparison of Carbonate Analyses, Site 64

\begin{tabular}{|c|c|c|c|c|c|c|}
\hline \multicolumn{4}{|c|}{ OSU Duplicate Analyses } & \multicolumn{2}{|c|}{ Nearest DSDP Value } & \multirow{2}{*}{$\begin{array}{l}\text { Difference between OSU and DSDP } \\
\text { values expressed as } \% \mathrm{CaCO}_{3}\end{array}$} \\
\hline Location & (1) & (2) & Average & Location & $\% \mathrm{C}$ & \\
\hline \multicolumn{7}{|l|}{$7-64.0$} \\
\hline $1-\mathrm{CC}$ & 10.04 & 10.05 & 10.05 & $1-6-88 \mathrm{~cm}$ & 9.86 & -1.5 \\
\hline 2-CC & 11.10 & 11.01 & 11.05 & $2-6-20 \mathrm{~cm}$ & 10.92 & -1.1 \\
\hline 3-CC & 11.50 & 11.38 & 11.44 & $3-6-50 \mathrm{~cm}$ & 10.52 & -7.7 \\
\hline 4-CC & 11.12 & 11.12 & 11.12 & $4-6-20 \mathrm{~cm}$ & 10.92 & -1.7 \\
\hline $5-\mathrm{CC}$ & 11.58 & 11.57 & 11.57 & $5-5-20 \mathrm{~cm}$ & 10.04 & -12.8 \\
\hline 6-CC & 11.45 & 11.67 & 11.56 & $6-5-20 \mathrm{~cm}$ & 9.12 & -20.3 \\
\hline 7-CC & 11.59 & 11.65 & 11.62 & $7-6-20 \mathrm{~cm}$ & 11.05 & -4.8 \\
\hline $8-\mathrm{CC}$ & 11.48 & 11.24 & 11.36 & $8-3-20 \mathrm{~cm}$ & 10.34 & -8.5 \\
\hline 9-CC & 11.60 & 11.73 & 11.67 & $10-1-27 \mathrm{~cm}$ & 10.62 & -8.7 \\
\hline \multicolumn{7}{|l|}{$7-64.1$} \\
\hline $1-\mathrm{CC}$ & 11.47 & 11.47 & 11.47 & $1-6-21 \mathrm{~cm}$ & 10.44 & -8.6 \\
\hline $2-\mathrm{CC}$ & 11.66 & 11.63 & 11.65 & $2-6-20 \mathrm{~cm}$ & 10.98 & -5.5 \\
\hline $3-\mathrm{CC}$ & 11.51 & 11.36 & 11.43 & $3-6-20 \mathrm{~cm}$ & 10.90 & -4.5 \\
\hline 4-CC & 11.09 & 11.05 & 11.07 & $4-6-20 \mathrm{~cm}$ & 10.50 & -4.8 \\
\hline $5-\mathrm{CC}$ & 11.36 & 11.39 & 11.37 & $5-6-20 \mathrm{~cm}$ & 10.64 & -6.1 \\
\hline
\end{tabular}

However, there is never any sparry calcite. Some of the deeper sections show anastomosing masses of reprecipitated silica permeating the chalk (Figures 9, 10 and 11). Variations in texture, that affect permeability, and in composition, that affect the micro-geochemical environment, seem to account for the local fluctuations in induration.

Pyrite is moderately common as an uthigenic mineral in these calcareous rocks. In several instances nodules several millimeters to a few centimeters long were exposed while splitting the cores or removing sediment samples. The elongate ellipsoid to prolate spheroid shapes suggest pseudomorphing of faecal pellets. Pyrite ranged in grain size down to less than a micron. In a few instances the pyrite was framboidal. Commonly, the interior of foraminifer walls are partly coated with fine pyrite (Figure 12). Disturbance of pyrite-rich beds and mottles by drilling or by splitting the cores tends to smear the purplish-black pyrite into the chalk ooze, making lighter tints of grayish purple.

According to the routine analyses from the shore-based laboratories reported elsewhere in this volume, these deep-water carbonates contain between 70 and 90 per cent calcium carbonate. In many instances the smear slides, insoluble residuals and thin sections examined by shipboard personnel had suggested that the carbonate content might be even greater. Analyses at Oregon State University consistently show more total carbon than the DSDP values (Table 1), and so it is strongly probable that the Leg 7 analyses of the calcium carbonate reported elsewhere in this volume may be as much as several percentage too low. 

Figure 1. Foraminiferal nannofossil chalk ooze, Ontong Java Plateau. Tests of foraminifers mainly are partly filled. Matrix is micrite, composed of nannofossils and some fragments of foraminifer tests. Tests at top left and center with pyrite grains (7-64-0-3-3-136 cm, Upper Miocene; plane light; scale bar $0.1 \mathrm{~mm}$ ).

Figure 2. Foraminiferal nannofossil limestone, East Caroline Basin. Tests of foraminifers calcified and partly filled with silica. Matrix is micrite composed of nannofossils and some fragments of foraminifers. Discoasters at left end and above center of scale bar (7-63-0-10-1032 cm; Oligocene inclusion in basalt; plane light; scale bar $0.1 \mathrm{~mm}$ ).
Figure 3. Foraminiferal nannofossil chalk, Ontong Java Plateau. Relative abundance of foraminifer tests define the lamination. Arrow indicates up 17-64-0-6-5-105 cm; Lower Miocene; plane light; scale bar $0.1 \mathrm{~mm}$ ).

Figure 4. Foraminiferal nannofossil chalk, Ontong Java Plateau. Relative abundance of foraminifer tests, and elongate fragments of tests, define the lamination. Arrow indicates up (7-65-0-6-6-65 cm; Lower Miocene; plane light; scale bar $0.1 \mathrm{~mm}$. 

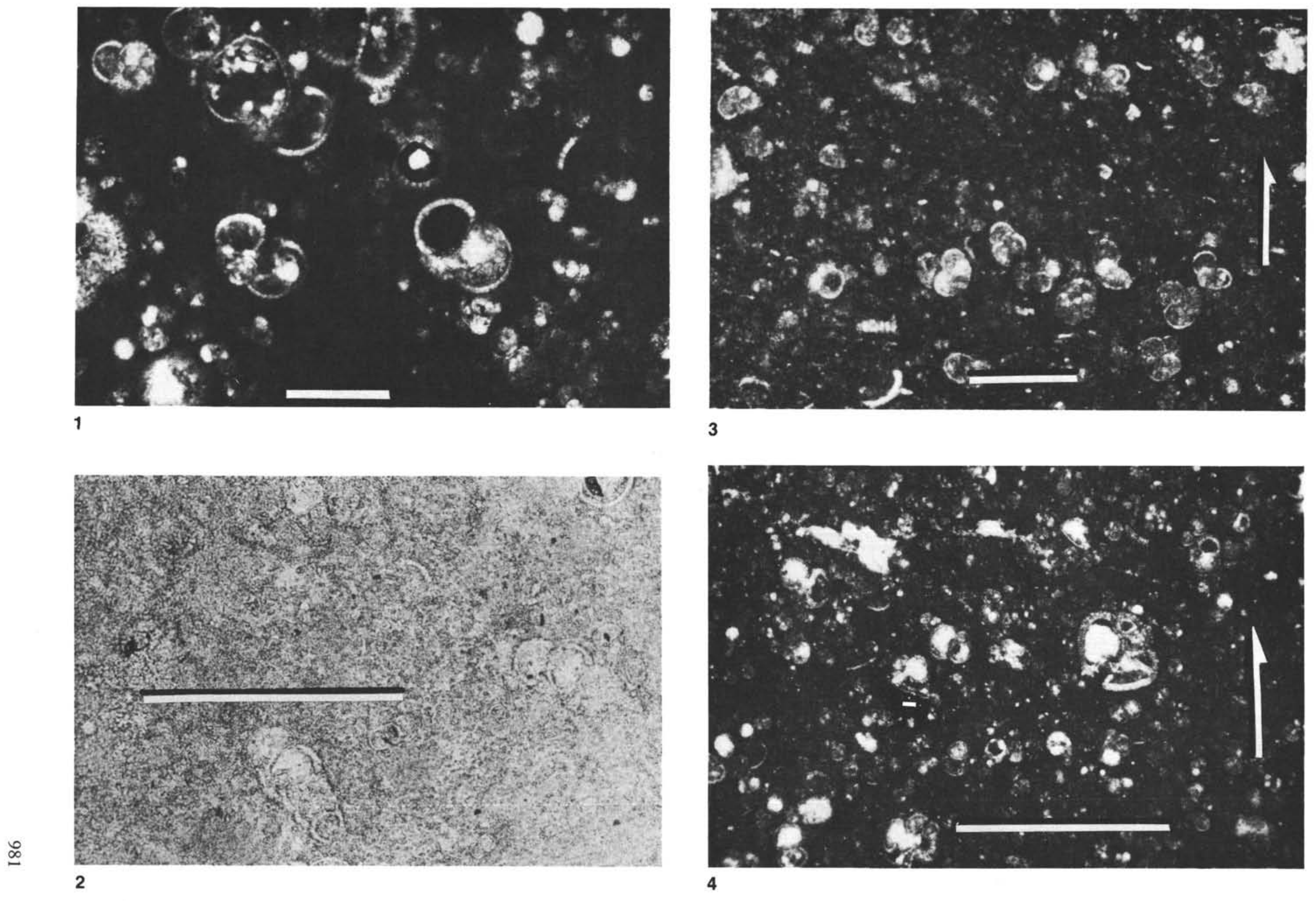
Figure 5. Foraminiferal nannofossil chalk, Eauripik Ridge. Crude fabric from alignment of long axes of some foraminifer tests. Packing is sparse; foraminifer tests are supported by nannofossil micrite and not by contact with one another. All tests are filled (7-62-0-8-cc; Upper Oligocene; plane light; scale bar $0.1 \mathrm{~mm}$ ).

Figure 6. Foraminiferal nannofossil chalk ooze, Ontong Java Plateau. Foraminifer tests are mainly unfilled to partly filled. Sample from about $2 \mathrm{~m}$ below sea floor (7-64-0-1-2-124 cm; Pleistocene; plane light; scale bar $0.1 \mathrm{~mm}$ ).
Figure 7. Foraminiferal nannofossil chalk, Ontong Java Plateau. Interiors of foraminifer tests are filled or nearly filled. Sample from about $513 \mathrm{~m}$ below sea floor (7-64-0-6-6-65 cm; Lower Miocene, N 5; plane light; scale bar $0.1 \mathrm{~mm}$ ).

Figure 8. Foraminiferal nannofossil chalk, Ontong Java Plateau. Two foraminifer tests at upper left have calcified walls and are completely filled, interiors of three lower ones partly replaced with cryptocrystalline silica. Arrow indicates up. Sample from about $970 \mathrm{~m}$ below sea floor (7-64-1-10-1-135 cm; Eocene, P-14 or older; plane light; scale bar $0.1 \mathrm{~mm}$ ). 

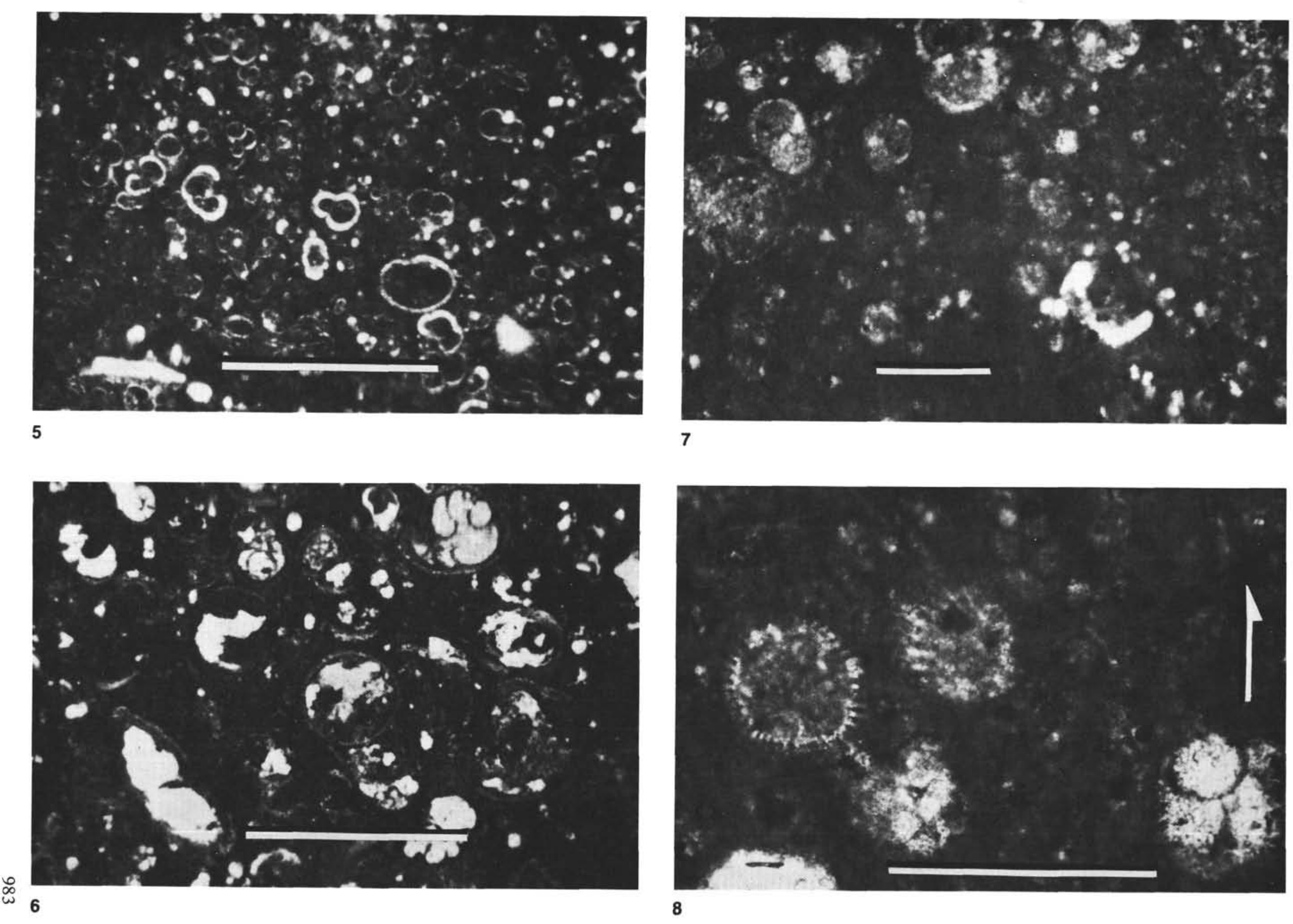
Figure 9. Siliceous foraminiferal nannofossil chalk ooze, Ontong Java Plateau. Mainly a firm chalk ooze, but contains irregular masses and bands of silica. In this illustration the light band from upper left diagonally to lower right is permeated with silica $17-64-1-4-2-36 \mathrm{~cm}$; Lower Miocene; plane light; scale bar $0.1 \mathrm{~mm}$ ).

Figure 10. Cherty, foraminiferal nannofossil limestone, Ontong Java Plateau. Foraminifer tests filled with micrite (gray) or chalcedony (light). Matrix is mainly microcrystalline calcite from nannofossils. Lighter patches within matrix are masses of silica that permeates the limestone, for example, upward from scale bar (7-64-0-10-2-64 $\mathrm{cm}$; Oligocene; plane light; scale bar $0.1 \mathrm{~mm}$.
Figure 11. Cherty, foraminiferal nannofossil limestone, Ontong Java Plateau. Heavily-calcified foraminifer tests in matrix of calcareous nannofossils. Large test in lower right has chamber lined with microcrystalline cristobalite and centers filled with quartz (7-64-1-11-cc; Eocene; crossed polarizers; scale bar $0.1 \mathrm{~mm}$ ).

Figure 12. Foraminiferal nannofossil chalk, Ontong Java Plateau. Pyrite (black) inside some foraminifer tests at upper right and lower center. Incipient chertification shown by patches of silica inside some tests, for example, light areas above left center of scale bar and elsewhere in center and lower right of field. Arrow indicates up (7-64-0-6-6-65 cm; Lower Miocene; plane light; scale bar $0.1 \mathrm{~mm}$ ). 

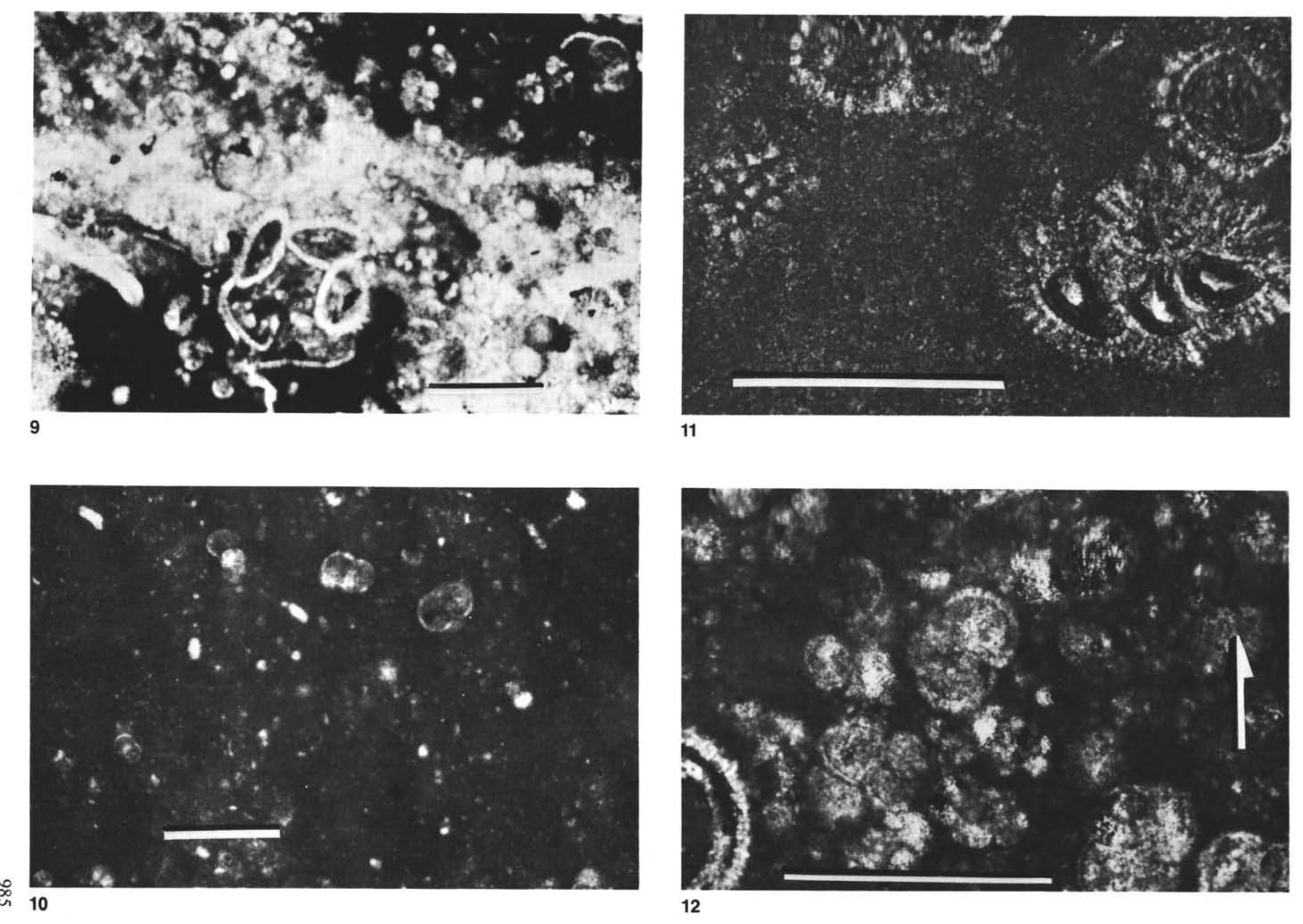